\title{
Studying International and European Law: Confronting Perspectives and Combining Interests
}

\author{
Ramses A. Wessel \\ Professor of International and European Law and Governance, University of Twente, The Netherlands*
}

Draft - to be published in in S. Garben and I. Govaere (Eds.), The Interface between International and EU Law, Oxford: Hart Publishers, 2018

\section{Introduction}

European law is international law, albeit perhaps a special branch in which, in particular, the link with domestic legal systems is further developed and the states have shown more willingness to transfer some of their competences to an international organization. The fact that European law does not exist in isolation, but is very well connected to other areas and levels of international law has become more apparent over the years. Part of the reason is to be found in the development of the European Union's so-called external relations, that is: the relations it has with non-EU member states and other international organizations. This development, which became even more clear with the focus of the 2009 Lisbon Treaty on the role of the EU as a global actor, ${ }^{1}$ underlines two dimensions of the interface between international and European law.

The first one is the effect of international law on the EU legal order. While the idea of the 'autonomy' of the EU legal order is still seen as a cornerstone for its functioning ${ }^{2}$ - perhaps in

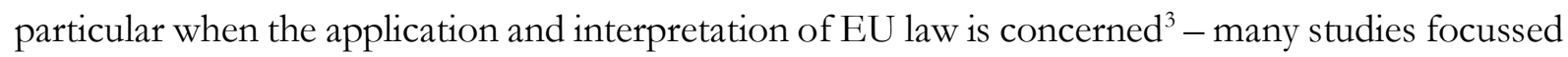
on the ways in which international law is received in the Union's legal order (often applying domestic constitutional analogies involving terms such as monism and dualism), or on the hierarchical position of international law among other norms (often concluding that it was placed somewhere between primary and secondary EU law). ${ }^{4}$ The overall consensus seems to be that, as

\footnotetext{
* Most parts of this paper were written as a Visiting Professor at LUISS Guido Carli and La Sapienza in Rome. Many thanks to Jan Klabbers and Bruno de Witte for their willingness to read an earlier version of this Chapter. Any omissions, unclarities or mistakes remain my own.

${ }^{1}$ See for instance the various contributions to B Van Vooren, S Blockmans and J Wouters (eds), The EU's Role in Global Governance: The Legal Dimension (Oxford, Oxford University Press, 2013); as well as, in particular, Arts. 3(5), 21 and 22 TEU.

2 Among the many publications on the autonomy of the EU, see recently for instance T Molnár, 'The Concept of Autonomy of EU Law from the Comparative Perspective of International Law and the Legal Systems of Member States' (2015) Hungarian Yearbook of International Law and European Law 433-459; as well as C Contartese, 'The Autonomy of the EU Legal Order in the CJEU's External Relations Case-Law: From the 'Essential' to the 'Specific Characteristics' of the Union and Back Again' (2017) Common Market Law Review 1-46.

${ }^{3}$ In Opinion 2/13, the Court of Justice of the European Union (CJEU) confirmed the complexities related to the EU's submission to external judicial scrutiny; Opinion 2/13 of the Court of 18 December 2014: Accession by the Union to the European Convention for the Protection of Human Rights and Fundamental Freedoms, ECLI:EU:C:2014:2454. See more generally M Cremona, A Thies and RA Wessel (eds), The European Union and International Dispute Settlement (Oxford, Hart Publishing, 2017).

${ }^{4}$ See for instance (and for further references) the contributions to E Cannizzaro, P Palchetti and RA Wessel (eds), International Law as Law of the European Union (Leiden/Boston, Martinus Nijhoff Publishing, 2011); RA Wessel, Close Encounters of the Third Kind: The Interface Between the EU and International Law after the Lisbon Treaty, (Sieps Report, 2013); K Ziegler, 'International Law and EU law: Between Asymmetric Constitutionalisations and Fragmentation' in A Orakhelashvili (ed), Research Handbook on the Theory and History of International Law' (Cheltenham, Edward Elgar, 2011)
} 
a matter of principle - and despite what has been viewed as a "tormented relationship" or "a source of great confusion" - the EU's order is open to international law; international commitments of the EU do have an effect internally and may even set aside secondary EU rules. And, in some occasions the EU has simply no choice but to accept international law in exercising its role as a global actor among states. ${ }^{6}$

The second dimension of the interface between international and European law is the influence of the EU on the international legal order (and on the domestic order of third states). Political science, in particular, has underlined and studied the role of the EU as a global normative actor, ${ }^{7}$ in particular in the promotion of its own values and by influencing global policy-making. More recently, the question of the external impact of EU rules and the ways in which these could form a legitimate source of international law, has also been picked-up by legal scholars. ${ }^{8}$ This may first of all have been triggered by the clear (some would perhaps prefer 'neo-colonialist') manner in which the EU treaties these days present the organization's ambitions to "uphold and promote its values and interests" in the wider world and to be guided by "the principles which have inspired its own creation" (Articles 3(5) and 21(3) TEU). Furthermore, these provisions make no mistake about not only the Union's intention to respect and observe international law, but also its promise to contribute to "the development of international law"."

268; K Ziegler, 'The Relationship between EU Law and International Law', University of Leicester School of Law Research Paper No. 15-04. See also V Moreno-Lax and P Gragl, 'Introduction: Beyond Monism, Dualism, Pluralism: The Quest for a (Fully-Fledged) Theoretical Framework: Co-Implication, Embeddedness, and Interdependency between Public International Law and EU Law' (2016) Yearbook of European Law; as well as the various other contributions to that special issue on EU Law and Public International Law: Co-implication, Embeddedness and Interdependency. ${ }^{5}$ Respectively J Wouters, 'The Tormented Relationship between International Law and EU Law', in PHF Bekker, R Dolzer, and M Waibel (eds), Making Transnational Law Work in the Global Economy: Essays in Honour of Detlev Vagts, (Cambridge, Cambridge University Press, 2010) 98-221; and J Klabbers, Treaty Conflict and the European Union (Cambridge, Cambridge University Press, 2009) ix.

6 An example is formed by the 'contracting-in' strategy of the EU in international diplomatic law in relation to the functioning of its representatives abroad and the so-called Union Delegations. See further below, as well as J Wouters and S Duquet, 'The EU and International Diplomatic Law: New Horizons?' (2012) Hague Journal of Diplomacy 31-49.

${ }^{7}$ See, for instance, I Manners, 'Normative Power Europe: A Contradiction in Terms?' (2002) 40 JCMS 235-258; H Sjursen, 'The EU as a Normative Power: How Can This Be?' (2006) 13 JEPP 235-151; R Whitman (ed.), Normative Power Europe: Empirical and Theoretical Perspectives (Palgrave, 2011); and T Forsberg, 'Normative Power Europe, Once Again: A Conceptual Analysis of an Ideal-type' (2011) 49 JCMS 1183-1204, at 1183. See also some chapters in N Witzleb, A Martínez Arranz, P Winand (eds), The European Union and Global Engagement: Institutions, Policies and Challenges, (Edward Elgar 2015). See for a critical assessment of political theories on this point, for instance, H Sjursen, 'Normative Theory: An Untapped Resource in the Study of European Foreign Policy', in KE Jørgensen, ÅK Aarstad, E Drieskens, K Laatikainen and B Tonra (eds), The SAGE Handbook of European Foreign Policy, Vol. 1 \& 2, (Sage, 2015) 197-213.

${ }^{8}$ See E Fahey, The Global Reach of EU Law (Abingdon and New York, Routledge, 2016); D Kochenov and F Amtenbrink (eds), The European Union's Shaping of the International Legal Order (Cambridge, Cambridge University Press, 2013); J Odermatt, The European Union as a Global Actor and its Impact on the International Legal Order, PhD thesis, University of Leuven, 2016; P Nevill, 'The European Union as a Source of Public International Law' (2013) Hungarian Yearbook of International Law and European Law 281-295 (Eleven International Publishing, 2014); F Hoffmeister, 'The Contribution of EU Practice to International Law', in M Cremona (ed), Developments in EU External Relations Law, (Oxford, Oxford University Press, 2008), 37-127; RA Wessel, 'Flipping the Question: The Reception of EU Law in the International Legal Order' (2016) Oxford Yearbook of European Law; and in the same volume T Konstadinides, 'Means of Interaction between EU and International Law: Customary International Law as a Source of EU Law: A Two-Way Fertilization Route?' (2016) Yearbook of European Law.

${ }^{9}$ Whether or not the EU is successful in that respect is also debated. See for instance KE Smith, 'The European Union at the Human Rights Council: Speaking with One Voice but Having Little Influence' (2010) Journal of European Public Policy 224-41; J Wouters, A-L Chané and J Odermatt, 'Improving the EU's Status in the UN and the UN System: An Objective Without a Strategy?, KU Leuven Centre for Global Governance Studies, Working Paper No 133 - March 2014. 
In that respect, earlier legal studies already addressed the question of the 'Europeanisation of international law', understood as dealing with the way in which international law is 'Europeanised' when it becomes part of the EU legal order (leading to questions on the emergence of a distinct European system of international law or the consequences of this 'Europeanisation' for the unity and coherence of public international law), ${ }^{10}$ as well as the normative aspects of making international law more 'European'. ${ }^{11}$

While the mutual influence of international and EU law thus seems to be generally acknowledged, EU law remains special. After all, it is not just law between states, but also within states. ${ }^{12}$ It is characterised by a number of elements that are often absent in other branches of international law: inter alia, primacy and direct effect, quite well-developed systems of political and judicial supervision, a directly elected parliament and, perhaps above all, a clear and quite extensive transfer of competences. All of this has turned the EU in something that is much more than a regular international organization and an entity that is increasingly assuming state-like functions. ${ }^{13}$

It is this 'specialness' of the EU that lies at the basis of the continued separation between the study of international law and EU law. Let's face it: in most educational programmes, international law and European law are taught in different courses. And in the event that they are combined, course outlines usually show different weeks for international and EU law. Textbooks in which international and EU law are combined in any conceptual fashion hardly exist. ${ }^{14}$ The same separation is visible in the research communities. International law scholars would generally be hesitant to teach EU law and vice versa, even at a very basic level. And, at ESIL conferences the present author meets a completely different crowd than at FIDE conferences. While 'EU external relations' used to be the area where international and EU law would necessarily be combined, even that field has developed into subject area of its own, with its own circle of specialists that have become more focussed on EU case law and questions of competence division than on learning to combine insights from both disciplinary perspectives. ${ }^{15}$ Indeed, few fora allow for an exchange of thoughts between international and European law and only few journals would be interested to publish in both areas.

\footnotetext{
${ }^{10}$ See J Wouters, A Nollkaemper and E de Wet (eds), The Europeanisation of International Law: The Status of International Law in the EU and its Member States (The Hague, T.M.C. Asser Press, 2008).

${ }^{11}$ See, on the idea of the EU as a 'model' for the international legal order, for instance, A Cassese, 'Towards a Moderate Monism: Could International Rules Eventually Acquire the Force to Invalidate Inconsistent National Laws?', in A Cassese (ed), Realizing Utopia: The Future of International Law (Oxford, Oxford Universoty Press, 2012), at 187; Slaughter and Burke-White, op.cit., at 327; M Weller, 'The Struggle for an International Constitutional Order', in D Armstrong (ed), Routledge Handbook of International Law (Routledge, 2009) 179-194, at 181. It has even been suggested that "the European example is now most often cited by international lawyers not by way of contrasting public international law regimes but by way of suggesting the probable or desired trajectory of some of the more specialized international law regimes". See JE Alvarez, International Organizations as Law-Makers (Oxford, Oxford University Press, 2006), at 468.

${ }^{12}$ See already the early statement that the EU "cannot be fitted into traditional categories of international or constitutional law"; HL Mason, The European Coal and Steel Community: Experiment in Supranationalism (Dordrecht, Martinus Nijhoff, 1955), 126.

${ }^{13} \mathrm{C}$ Eckes and RA Wessel, 'The European Union: An International Perspective', in T Tridimas and R Schütze (eds), The Oxford Principles of European Union Law - Volume 1: The European Union Legal Order (Oxford, Oxford University Press, 2017) (forthcoming).

14 To overcome this, the present author co-wrote a new Dutch textbook that was initially quite well used at Dutch universities offering a course on 'international and European law'. After a few years, however, the integrated approach offered by the book proofed to be difficult to match the course outlines, which preferred to deal with the issues separately. See WG Werner and RA Wessel, Internationaal en Europees recht: Een verkenning van grondslagen en kenmerken (Groningen, Europa Law Publishing, 2011, 3rd ed.).

${ }^{15}$ cf J Larik, 'EU Foreign Relations Law as a Field of Scholarship' (2017) AJIL Unbound, 111, 321-325.
} 
Yet, the links between the two areas are obvious, as also reflected in the other contributions to this book. The European Union was established by a treaty concluded by sovereign states and many international law issues recur within the EU. One may think of methods for the interpretation of treaty provisions, questions on the legal personality of EU Institutions or agencies, or the need to respect commitments in good faith. Also other issues, such as the rules on the Stability Pact, the voting arrangements in the Council, the late implementation of EU legislation by Member States or the relatively limited competences of the European Parliament are understandable only with some knowledge of the nature and structure of the international system.

This contribution does not aim to add to the extensive body of knowledge on the relationship between international and European law, to which the present Volume contributes in such an excellent way. Rather, it raises a meta question by asking to what extent - given the noncontested interrelationship between international and EU law - both disciplines could benefit from each other's insights. It is argued that to better understand EU law, it would also make sense for students to be confronted with the interface with international law rather than with the mere 'specialness' of their object of study; and to better understand international law, it may be useful to keep an eye on the way it develops in and around the EU. As argued by Ličková on the separate study of international and EU law: "Such partial inquiries are useful, but they remain incomplete because both legal orders intervene and interplay when normative conflicts between them appear." ${ }^{" 16}$ Admittedly, the same holds true for other academic sub-disciplines. Thus, findings in national constitutional law should be compared more with global and European constitutional developments, ${ }^{17}$ and knowledge of private law helps one understand the logic of treaty law and the law of responsibility. ${ }^{18}$ More in general, the "triangular relationship between EU law, international law and the EU Member States"19 forces us to continue to study international, EU and domestic law with an open eye to the increasing opportunities of legal systems to influence each other. ${ }^{20}$ Yet, the present Chapter will focus on international and EU law only. The aim is even more modest, as the available space merely allows for a first inquiry, allowing for future research to further analyse and develop the various themes. This Chapter will start by confronting the perspectives both academic disciplines have on each other (section 2). The risk that the presentations of these disciplines result in the creation of strawmen (as classifications may be based on this author's own perceptions $^{21}$ ) will, hopefully, be mitigated by a number of references to different sources. The

${ }^{16}$ cf M Ličková, 'European Exceptionalism in International Law' (2008) EJIL, 463-490, at 465.

17 cf Ziegler, 'The Relationship between EU Law and International Law', above, at 2: "the Court of Justice of the EU $(\mathrm{CJEU})$ adopts a strong constitutionalist approach which assimilates the relationship between EU law and international law in many respects to the relationship between international law and national law. The EU's approach to international law may be motivated by inward-looking (constitutional) considerations that may be instrumental to its own dynamics, constitutional narrative and trajectory." Compare on the transnational dimensions of the constitutional debate $\mathrm{N}$ Walker, Intimations of Global Law (Cambridge, Cambridge University Press, 2014).

${ }^{18}$ cf S. Kadelbach, "From Public International Law to International Public Law: A Comment on the "Public Authority" of International Institutions and the "Publicness" of their Law', in A von Bogdandy, R Wolfrum, J von Bernstorff, P Dann, M.Goldmann (eds), The Exercise of Public Authority by International Institutions (Berlin/Heidelberg, Springer, 2010), 33-49.

${ }^{19}$ Ziegler, 'The Relationship between EU Law and International Law', above, at 2

$20 \mathrm{cf}$ the contributions to A Føllesdal, RA Wessel and J Wouters (eds), Multilevel Regulation and the EU: The Interplay between Global, European and National Normative Processes (Leiden/Boston, Martinus Nijhoff Publishers, 2008); as well as E Nijman and A Nollkeamper (eds), New Perspectives on the Divide Between National and International Law (Oxford, Oxford University Press, 2007).

${ }^{21}$ Indeed, a priori perceptions matter and do influence the debate as well as the conclusions. As recently held by Binder and Hofbauer: "In particular the classification of the EU as a subsystem of international law, as a de facto domestic order, or as a sui generis legal order predetermines which conflict rules and reconciliatory techniques find application." 
confrontation of perspectives will be followed by mapping a number of areas of potential common interest (section 3). Section 4, finally, will try and answer the question of whether it makes sense to study both disciplines in a more integrated fashion.

\section{Mutual perspectives}

\subsection{An international law perspective on the European Union}

As an international entity, the European Union can obviously be studied from the perspective of international law. ${ }^{22}$ Yet, international law's focus is mainly on states. Only states are vested with 'original rights' and hence are 'primary subjects' of international law. ${ }^{23}$ And even though other international actors accept that the Union takes at times a state-like position, "the EU is, under international law, precluded by its very nature from being considered a State". ${ }^{24}$ At the same time, international law also deals with international organizations, and the EU can be classified as one. ${ }^{25}$ Nevertheless, the special relationship with its Member States is unique in the law of international organizations and even in that field, the EU is often set apart.

Indeed, is has been argued that the EU is "an international legal experiment". ${ }^{26}$ Few would argue that the $\mathrm{EU}$ is a state, ${ }^{27}$ many would evade the question and say that it is an international entity sui generis. ${ }^{28}$ International law, however, only works when it is applied across the board for certain categories of international actors. Its rationale is to offer clarity and set the conditions for a smooth cooperation between different subjects. At the same time, it is of course possible to create special rules for special entities. The clauses on Regional Economic Integration Organizations (REIOs) in some multilateral agreements ${ }^{29}$ are a good example.

\footnotetext{
C Binder and JA Hofbauer, 'The Perception of the EU Legal Order in International Law: An In- and Outside View' (2017) European Yearbook of International Economic Law 139-203, at 142.

22 See also Eckes and Wessel, above. Some arguments in this section are derived from that paper.

${ }^{23}$ A Carty, Philosophy of International Law, Edinburgh: Edinburgh University Press, 2007, Chapter 3, International Legal Personality, p. 81. See also: International Court of Justice, Reparation For Injuries Suffered In The Service Of The United Nations, Advisory Opinion of 11 April 1949 (the Reparations case, ICJ Reports, 1949, p. 174), discussed below.

${ }^{24}$ CJEU, Opinion 2/13 of 18 December 2014, para 156.

25 At best as a particular type of international organization that enjoys additional rights in certain contexts, a regional economic integration organization (REIO). See further below.

${ }^{26}$ B De Witte, 'The European Union as an International Legal Experiment', in G De Búrca and JHH Weiler (eds), The Worlds of European Constitutionalism (Cambridge, Cambridge University Press, 2011) 19-56.

${ }^{27}$ As noted above this was (for the first time) underlined by the CJEU in Opinion 2/13, para 156. Yet, it can be argued that there are close resemblances with federations; see further below.

${ }^{28}$ Yet, see the (rightful) critique on the use of the 'sui generis' notion by R Schütze, 'On "Federal" Ground: The European Union as an (Inter)national Phenomenon' (2009) CMLR 1069-1105, at 1091-1092. Republished in R Schütze, Foreign Affairs and the EU Constitution: Selected Essays (Cambridge, Cambridge University Press, 2014 ), ch 1.

${ }^{29}$ A REIO is commonly defined in UN protocols and conventions as "an organization constituted by sovereign states of a given region to which its member states have transferred competence in respect of matters governed by [...] convention or its protocols and [which] has been duly authorized, in accordance with its internal procedures, to sign, ratify, accept, approve or accede to it [the instruments concerned]." See for example the 2004 Energy Charter Treaty (Art. 3). See also E Paasivirta and PJ Kuijper, 'Does one size fit all?: The European Community and the Responsibility of International Organisations' Netherlands Yearbook of International Law, 2005 (The Hague, T.M.C. Asser Press, 2007) 169-226 at 205. In the new Convention on the Rights of Persons with Disabilities the REIO clause seems to have evolved to a RIO (Regional Integration Organisation) clause, which does justice to the large scope of activities of the EU these days (see Art. 44: "'Regional integration organisation' shall mean an organisation constituted by sovereign States of a given region, to which its member States have transferred competence in respect of matters governed by this Convention.")
} 
To deal with the fact that the EU is more than a regular international organization, the term 'integration organization' is often used, implying that from the perspective of international law, the Union is an international organization that at times requires adaptation of the usual paradigms applied to international organizations and that the sovereignty of Member States has not been taken away but has adapted. The Union may not possess original sovereign rights, except for from its own perspective, but it has been successful in changing the international position and the selfconception of its Member States. ${ }^{30}$ Indeed, EU membership has transformed States into Member States, both internally and externally.

Yet, international lawyers would argue that "[f]rom an international law perspective, there is no reason to per se 'detach' the EU from the international legal framework". ${ }^{31}$ Irrespective of the difficulty to classify the European Union from the perspective of international law, there is agreement that, as an international actor, the $\mathrm{EU}$ is subject to international law in its relations with third states and international organizations. ${ }^{32}$ It is bound by the international agreements to which it is a party as well as to customary international law. ${ }^{33}$ More recent developments show that international law is indeed capable of taking the differences between states and international integration organizations into account. ${ }^{34}$ This is particularly relevant as in recent years, the EU has been taking up 'state-like functions' in more areas than before. ${ }^{35}$ This is partly due to the fact that the introduction of the European External Action Service (EEAS) ${ }^{36}$ led to a professionalization of the EU's diplomatic network around the world. The EU's physical presence through its delegations is based on Article 221(1) TFEU: "Union Delegations in third countries and at international organizations shall represent the Union." Indeed, distinctions with states representations are increasingly blurred. Heads of Delegations de facto act as 'EU ambassadors', and the EU adapts international diplomatic law to be able to 'play along. ${ }^{37}$

The EU is also quite visible in international law as it regularly concludes international agreements with third countries, ie. non-Member States. ${ }^{38}$ It's international legal personality was

\footnotetext{
${ }^{30}$ On the latter see C Bickerton, European Integration (Oxford, Oxford University Press, 2012). See more extensively Eckes and Wessel, above.

${ }^{31}$ Binder and Hofbauer, above, at 141. Compare also B Simma and D Pulkowski, 'Of Planets and the Universe: SelfContained Regimes in International Law' (2006) EJIL 483-529, at 516: “The continuous assertion of the Community's sui generis character $[\ldots]$ does not by itself create an 'own legal order'. From a public international law perspective, the EC legal system remains a suborder of international law."

32 See for a survey of the many facets of the relationship between international and EU law: RA Wessel, Close Encounters of the Third Kind: The Interface Between the EU and International Law after the Lisbon Treaty, Stockholm: Sieps Report, 2013.

33 More extensively: ibid, p. 106. See also clearly the judgment of the CJEU in case C-366/10, Air Transport Association of America, American Airlines Inc., Continental Airlines Inc., United Airlines Inc. v. Secretary of State for Energy and Climate Change, 2011.

${ }^{34}$ Respectively to be found at < http://untreaty.un.org/ilc/texts/instruments/english/conventions/1_2 1986.pdf $>$; and $<$ http://untreaty.un.org/ilc/texts/instruments/english/draft $\% 20$ articles/9 11 2011.pdf $>$. Obviously, the extent to which these instruments successfully take the complex position of international organizations into account may be subject to debate.

${ }^{35}$ See more extensively RA Wessel, 'Can the European Union Replace its Member States in International Affairs? An International Law Perspective’, in I Govaere, E Lannon, P Van Elsuwege, S Adam (eds), The European Union in the World: Essays in Honour of Marc Maresceau (Leiden/Boston, Martinus Nijhoff Publishers, 2013) 129-147; as well as Wouters and Duquet, above.

36 M Gatti, European External Action Service: Promoting Coherence through Autonomy and Coordination (Leiden/Boston, Brill | Nijhoff, 2016); J Bátora and D Spence (eds), The European External Action Service: European Diplomacy Post-Westphalia (Basingstoke, Palgrave MacMillan, 2015).

37 Wouters and Duquet, above; see also F Fenton, 'EU Ambassadors: A New Creed?', in P Quinn (ed), above, 26-30; P Kerres and RA Wessel, 'Apples and Oranges? Comparing the European Union Delegations to National Embassies' (2015) CLEER Papers, No.2.

${ }^{38}$ For an overview see: https://treaties.un.org/.
} 
confirmed in the current Treaties. ${ }^{39}$ Since the entry into force of the Lisbon Treaty, the Union has succeeded the Community and taken over all international obligations flowing from the latter's treaty making activities over the first decades. This separate legal status in international law also confirmed a separate role of the EU in international institutions, mostly alongside its Member States. Thus, the EU is a full member of a number of international organizations, including the World Trade Organization (WTO), the Food and Agriculture Organization (FAO) ${ }^{40}$ the Codex Alimentarius, as well as of most fisheries organizations; ${ }^{41}$ and an observer to many other international organizations. Indeed, its engagement with a large number of IO's has made it a visible actor in the international legal order. ${ }^{42}$

Apart from the claim for autonomy by EU law, which may lead to fragmentation and an undermining of the international dispute settlement system (see below), ${ }^{43}$ most problematic perhaps from an international law perspective is the complex division of competences between the EU and its Member States. ${ }^{44}$ The starting point is given in treaty law, pursuant to which an international organization may not invoke the rules of the organization as justification for its failure to perform a treaty (Art. 27(2), 1986 Vienna Convention). Article 46 (2) of the 1986 Convention adds that an international organization may not invoke the fact that its consent to be bound by a treaty has been expressed in violation of the rules of the organization regarding competence to conclude treaties as invalidating its consent unless that violation was manifest and concerned a rule of fundamental importance. Article 46(3) specifies that a violation is manifest if it would be objectively evident to any State or any international organization conducting itself in the matter in accordance with the normal practice of States and, where appropriate, of international organizations and in good faith. ${ }^{45}$ Given the manifold international relations and the dynamic and extensive competences of the Union, the question comes up to what extent the division of competences should be objectively evident to other international actors. It has been argued that once this division is made known, the rules are no longer purely internal, but may form part of the international agreements, or at least form a source for interpretation. ${ }^{46}$ This would in particular be true in cases where a 'declaration of competence' has been issued by the EU. ${ }^{47}$ The division of

\footnotetext{
39 Article 47 TEU: "The Union shall have legal personality."

40 Articles II (8)-(11) FAO Constitution.

${ }^{41}$ See RA Wessel, 'The Legal Framework for the Participation of the European Union in International Institutions', in S Oberthür, KE Jorgenson and J Shahin (eds), The Performance of the EU in International Institutions (London/New York, Routledge, 2013), 23-37 (also published in Journal of European Integration, 2011).

${ }^{42}$ See RA Wessel and J Odermatt (eds), Research Handbook on the EU's Engagement with International Organizations (Edward Elgar Publishing, 2018) (forthcoming)

${ }^{43}$ See extensively on these issues Binder and Hofbauer, above.

${ }^{44}$ See, among the many studies in this topic, recently S Garben and I Govaere (eds), The Division of Competences between the EU and the Member States: Reflections on the Past, the Present and the Future (Oxford, Hart Publishing, 2017).

45 This seems to have been accepted by the European Court of Justice as well. See for instance the cases France v. Commission (C-327/91, Jur. 1994, I-3641) and the PNR-cases in Joined Cases C-317/04 and C-318/04 European Parliament v. Council and Commission [2006] ECR I-04721.

46 'European Union External Action and International Law', CAVV Advisory Report No. 24, 2014; http://cms.webbeat.net/ContentSuite/upload/cav/doc/CAVV_Advisory_Report_EU_External_Action_and_Inter national_Law(1).pdf.

${ }^{47}$ See for an overview of "Agreements with a declaration of competence by the EU" the website of the EU Treaties Office: http://ec.europa.eu/world/agreements/viewCollection.do. See on the declarations also J Heliskoski, 'EU Declarations of Competence and International Responsibility', in M Evans and P Koutrakos (eds), International Responsibility: EU and International Perspectives (Oxford, Hart Publishing, 2013), pp. 189-212; and more recently A. Delgado Casteleiro, The International Responsibility of the European Union: From Competence to Normative Control (Cambridge, Cambridge University Press, 2016).
} 
competences and its consequences under international law will return in some of the analyses below (section 3).

\subsection{A European law perspective on the international legal order}

EU legal scholars would generally see international law as less complex, less technical and perhaps even closer to politics than to law. They wonder what the ICJ judges are doing the entire day with so few cases to handle and how international law scholars spend their day without having to deal with events on a daily basis. Obviously, they deny the fact that law is not just about case law or legal instruments that are adopted on a constant basis, but also, or perhaps mainly, about interpretation. And that is not so different from what they do in EU law. International law is based on many international agreements and on custom and apart from the ICJ there are many more tribunals involved in international dispute settlement. ${ }^{48}$ And, are treaty law, the law of responsibility, or international trade or environmental law - to name just a few - really less 'technical' and less complex than EU law?

It is well-known that EU legal scholars have a tendency to stress the 'specialness' (and related 'autonomy') of the EU. Obviously, the early case law of the Court had set a trend in that respect. We all remember the famous qualification by the Court in Van Gend \& Loos of the Community as "a new legal order of international law for the benefit of which the states have limited their sovereign rights, albeit within limited fields and the subjects of which comprise not only member states but also their nationals." ${ }^{49}$. There has been some debate on whether Van Gend \& Loos should be seen as a logical follow-up to choices made in the Treaties and earlier case law of the Court, ${ }^{50}$ or that it "should be understood as a decisive turning point in the history of the ECJ and of European law in general." 51 In the latter view "The judgment constituted at the most fundamental level an attempt to differentiate European law from what was perceived as traditional international public law. A process completed when the ECJ in the Costa v. E.N.E.L. judgment termed the European legal order merely as a "new legal order"". ${ }^{2}$ While all of this may have resulted in "a partly autistic approach of the EU Institutions towards international law", 53 it remains worth noting that the Court itself "never sought to develop a doctrine affirming the specific and noninternational nature of the EU." 54 The separation between the two disciplines is largely a scholarly invention.

\footnotetext{
48 In a recent study, Alter counted seventeen international courts with a competence to settle disputes; see KJ Alter, The New Terrain of International Law: Courts, Politics, Rights (Princeton/Oxford, Princeton University Press, 2014), Chapter 5. See on different forms of IDS also L Boisson de Chazournes, MG Kohen, JE Vinuales (eds), Diplomatic and Judicial Means of Dispute Settlement (Leiden/Boston, Martinus Nijhoff Publishers, 2013).

${ }^{49}$ Case 26/62, NV Algemene Transport- en Expeditie Onderneming van Gend \& Loos v Netherlands Inland

Revenue Administration; ECLI:EU:C:1963:1.

${ }^{50}$ See for instance JHH Weiler, 'Rewriting V an Gend en Loos: Towards a Normative Theory of ECJ Hermeneutics', in O Wiklund (ed), Judicial Discretion in European Perspective, 2003, 150, at 150-151: "V an Gend en Loos and its progeny are not the result of a new hermeneutics and that the decision would, or at least could, be the same under the traditional rule of interpretation of public international law." Compare also D Edwards, "Judicial Activism-Myth or Reality? Van Gend en Loos, Costa v. ENEL and the V an Duyn Family Revisited, in AIK Campbell and M Voyatzi (eds), Essays in the Honour of Lord Mackenzie-Stuart (1996), 29.

${ }^{51}$ M Rasmussen, 'Revolutionizing European Law: A History of the Van Gend en Loos Judgment' (2014)12 International Journal of Constititutional Law 1, 136-163.

52 Ibid. See on different analyses of the case also A Tizzano, J Kokott, S Prechal (eds), $50^{\text {th }}$ Anniversary of the judgment in Van Gend en Loos, 1963-2013 (Luxembourg, European Court of Justice, 2013).

${ }^{53}$ Binder and Hofbauer, above, at 155.

${ }^{54}$ B de Witte, 'EU Law: Is it International Law?', in C Barnard and S Peers (eds), European Union Law (Oxford, Oxford University Press, 2017) (2nd ed.), 177-197 at 182.
} 
There are good arguments to continue viewing EU law as part of international law. After all, it is based on treaties that were concluded under international law and the chosen form of institutional cooperation was (and is) made possible by international law. ${ }^{55}$ Yet, with the continued integration process, the divide between international and EU law studies deepened and distinctions rather than similarities dominated the debate. ${ }^{56}$ As one observer held: "even if the EEC did conform to the status of international organizations in its early days (which is unlikely) it has now moved well beyond that." ${ }^{57}$ Or, "[]n the eyes of the European Court and the majority of European scholars, the normative force of European law derives no longer from the normative foundations of international law. The ultimate normative base within the European Union - its "originality hypothesis" or "Grundnorm" - is the Rome Treaty as such." 58 Notions like these have seriously influenced the EU's self-perception in relation to international law.

EU scholars have increasingly made comparisons to 'statehood', rather than to 'organizationhood'. ${ }^{59}$ Notions like the one by the Court in Van Gend \& Loos that "[i]ndependently of the legislation of member states, community law [...] not only imposes obligations on individuals but is also intended to confer upon them rights which become part of their legal heritage", seem to have steered EU law scholarship in a that direction. Rather than viewing EU law as a special branch of international law, EU scholarship turned to state-like metaphors. ${ }^{60}$ Thus, analyses have assessed the EU as a confederation, ${ }^{61}$ or even in federal terms. ${ }^{62}$ The federative argument was for instance presented by Schütze when he argued in relation to the EU that: "Its formation was clearly international and its amendment still is. However, its international birth should not prejudge against the 'federal' or 'constitutional' status of the EC Treaty. [...] The fact remains that the European legal order has adopted the 'originality hypothesis' and cut the umbilical cord with the international legal order. The Treaty as such - not international law - is posited at the origin of European law.

\footnotetext{
${ }^{55}$ Ibid. at 178.

${ }^{56}$ For an early and influential publication in that respect, see P Pescatore, 'International Law and Community Law A Comparatice Analysis' (1970) CMLR 167.

${ }^{57}$ S Douglas-Scott, Constitutional Law of the European Union (London, Longman, 2002), at p. 260; as well as JHH Weiler and UR Haltern, 'Constitutional or International? The Foundations of the Community Legal Order and the Question of Judicial Kompetenz-Kompetenz', in A-M Slaughter, A Stone Sweet and JHH Weiler (eds), The European Courts and National Courts: Doctrine and Jurisprudence (Oxford, Hart Publishing, 1998), 331, at 342; but many more similar quotes can be found.

${ }^{58}$ R Schütze, 'On “Federal” Ground: The European Union as an (Inter)national Phenomenon' (2009) CMLR 1069_ 1105, at 1082. Republished in R Schütze, Foreign Affairs and the EU Constitution: Selected Essays (Cambridge, Cambridge University Press, 2014), Chapter 1. In the last sentence quoting Madison, The Federalist No. 39, in Hamilton, Madison, and Jay, The Federalist (Cambridge, Cambridge University Press, 2003), at p. 187.

${ }^{59}$ cf GF Mancini, 'Europe: The Case for Statehood' (1998) European Law Journal, 29.

${ }^{60}$ See for a short analysis of the various notions, including 'supranational organization', 'Statenverbund', or 'constitutional order of States' also De Witte, above, at 191.

${ }^{61}$ A Cuyvers, 'The Confederal Comeback: Rediscovering the Confederal Form for a Transnational World', 19 European Law Journal (2013) 711-738. See also his thesis defended at the University of Leiden: The EU as a Confederal Union of Sovereign Member Peoples: Exploring the potential of American (con)federalism and popular sovereignty for a constitutional theory of the EU, Meijers-series no. MI-227 (Leiden, Wohrmann / Meijers, 2014).

${ }^{62}$ See for instance M Cappelletti, M Secombe and JHH Weiler (eds), Integration through Law_Europe and the American Federal Experience, Vol. I, (De Gruyter, 1986); K Lenaerts, 'Federalism: Essential Concepts in Evolution-the Case of the European Union', (1998) 21 Fordham International Law Journal 746; A von Bogdandy, 'The European Union as a Supranational Federation: A Conceptual Attempt in the Light of the Amsterdam Treaty', (2000) 6 Columbia Journal of European Law 27; R Schütze, 'On 'Federal”' Ground: the European Union as an (Inter)National Phenomenon', (2009) 46 Common Market Law Review 1096; JHH Weiler, 'The Transformation of Europe' (1991) Yale Law Journal, 2403-2484; G De Baere and K Gutman, above. And, as a warning against too much federalism: SJ Boom, 'The European Union After the Maastricht Decision: Will Germany Be the Virginia of Europe?', American Journal of Comparative Law (1995) $177-226$ at 208 .
} 
Functionally, then, the European Union is based on a 'constitutional treaty' that assumes and stands on federal middle ground." 63 It has also been argued that "the EU has combined a confederal foundation with some crucial federate reinforcements in its constitutional superstructure." ${ }^{64} \mathrm{As}$ indicated supra, only recently the EU Court for the first time expressly stated that the EU is not a state. $^{65}$

All in all, the debate in the EU has much more been on its nature and on the relations with its Member States (and the related division of powers) than on a comparison with international law. Since this original conception of permanently transferred sovereign rights, the Court and the Treaties, have hand in hand, pushed forward a process of fortifying the European construction.

\section{Mutual interests}

The purpose of the present contribution is not to deny the above findings, but to map areas in which international and EU law can - nevertheless - learn from each other and where a dialogue should continue. The list below is by no means meant to be exhaustive; it merely aims to give an indication of possible mutual interests.

\subsection{The nature of the legal system}

One of the popular differences between international and EU law is the different nature of their legal orders (see also supra: law between states or (also) law within states). Yet, also international law has moved from just being inter-state law, to law that can have an effect on the relations between governments and their individuals. Obvious examples include human rights law and international criminal law. International law seems to have realised that many problems are domestic and that in the words of Slaughter and Burke-White - "To create desirable conditions in the international system, from peace, to health to prosperity, international law must address the capacity and the will of domestic governments to respond to these issues at their sources. In turn, the primary terrain of international law must shift - and is already shifting in many instances - from independent regulation above the national state to direct engagement with domestic institutions." ${ }^{\prime 66}$ These authors have argued that what international law needs is "a direct emphasis on shaping or influencing political outcomes within sovereign states in accordance with international legal rules" and a "European way of law" should be at the basis of a transformation of international law. ${ }^{67}$ In particular agreeing on objectives (in 'Directives'), while leaving the (most suitable form of) implementation to the states, would better help international law attain many of its goals. The authors look somewhat jealously to "the EU's 'soft' intervention in the 'domestic affairs' of EU member states" on an almost daily basis. ${ }^{68}$ Furthermore, the EU is not seldomly mentioned as a

\footnotetext{
${ }^{63} \mathrm{R}$ Schütze, above, at 1089. Republished in R Schütze, Foreign Affairs and the EU Constitution: Selected Essays (Cambridge, Cambridge University Press, 2014), Chapter 1; in the last sentence quoting Madison, The Federalist No. 39, in Hamilton, Madison, and Jay, above, 187.

64 A Cuyvers, above, at 712 .

${ }^{65}$ Opinion 2/13 of the Court of 18 December 2014 on the accession of the EU to the ECHR, ECLI:EU:C:2014:2454, par. 49.

${ }^{66}$ A-M Slaughter and W Burke-White, 'The Future of International Law Is Domestic (or, The European Way of Law)', Harvard International Law Journal (2006), No. 2, 327-352, at 328.

${ }^{67}$ Ibid.

${ }^{68}$ Ibid. at 133.
} 
blueprint for other regions in the world and comparisons with the African Union, ASEAN or MERCOSUR are often made to see whether the 'European way of law' could be helpful in other areas of the world as well. The EU itself has even claimed that these forms of integration "make an important contribution to a more orderly world." ${ }^{\prime 9}$

While there are certainly lessons to draw from the way in which European law interacts with domestic legal orders, it is obvious why many of the starting point are hardly translatable to a wider context. The European Union started with a few states only and in a very specific period in time. Sixty years and twenty-two more members later, the limits of the project are becoming more visible.

\subsection{Constitutionalism and effects on individuals}

The nature of the two legal orders is closely related to another development which is prominent in both international and EU law: a constitutional approach. This approach, with a focus on checks and balances and rights of individuals, has of course been part and parcel of EU-studies from the outset. $^{70}$ These days it is also no longer uncommon to view the international legal order in constitutional terms, and 'international constitutional law' has slowly become a special area of study. ${ }^{71}$ As in European Union law, the effects of rules and legislation on individuals also triggered this development in international law. The proliferation and law-making, ${ }^{72}$ or even legislative, ${ }^{73}$ functions of many international organizations made us aware of the existence of - perhaps not the emergence of a world government ${ }^{74}$ - but at least of global governance 'beyond the state ${ }^{75}$ in what is sometimes normatively framed in familiar 'communitarian' terms: a 'world community'. ${ }^{76}$

\footnotetext{
692003 European Security Strategy, 'A secure Europe in a better world'.

70 See, e.g. A Stone Sweet, Govering with Judges: Constitutional Politics in Europe (Oxford, Oxford University Press, 2000); J Weiler and M Wind (eds), European Constitutionalism beyond the State (2003); N Walker, 'European Constitutionalism in the State Constitutional Tradition', in C Holder, C O'Cinneide and C Campbell-Holt (edds), Current Legal Problems (Oxford, Oxford University Press, 2006) 51-89.

${ }^{71}$ Among the many publications in this area cf. Chapter 2, 'The Transfer of the Constitutional Idea to the Sphere of International Law: Different Approaches' in B Fassbender, The United Nations Charter as the Constitution of the International Community (Leiden/Boston, Brill, 2009); A Paulus, 'The International Legal System as a Constitution', in JL Donoff and JP Trachtman (eds), Ruling the World? Constitutionalism, International Law and Global Governance (Cambridge, Cambridge University Press, 2009) 69-109; J Klabbers, A Peters and G Ulfstein (eds), The Constitutionalization of International Law (Oxford, Oxford University Press, 2009); E De Wet, 'The International Constitutional Order', International and Comparative Law Quarterly (2006) 51-76; R St J MacDonald and DM Johnston, Towards World Constitutionalism - Issues in the Legal Ordering of the World Community (Leiden/Boston, Martinus Nijhoff Publishers, 2005); as well as Christine EJ Schwöbel, Global Constitutionalism in International Legal Perspective (Leiden/Boston, Brill, 2011).

72 See for a recent analysis ND White, 'Lawmaking' in J Cogan, I Hurd and I Johnston (eds), Oxford Handbook of International Organizations (Oxford, Oxford University Press, 2016); as well as the various contributions to C Bröllman and Y Radi (eds), Research Handbook on the Theory and Practice of International Lawmaking (Cheltenham/Northhampton, Edward Elgar Publishing, 2016).

${ }^{73}$ This discussion primarily took place in relation to the UN Security Council. See or instance cf PC Szasz, 'The Security Council Starts Legislating', American Journal of International Law (2002) 901-905; S Talmon, 'The Security Council as World Legislature', American Journal of International Law (2005), 175-193; B Elberling, 'The Ultra Vires Character of Legislative Action by the Security Council', International Organizations Law Review (2005), 337-360; M Akram, and SH Shah, 'The Legislative Powers of the United Nations Security Council', in MacDonald and DM Johnston, above, 431455.

${ }^{74}$ Yet, see JP Trachtman, The Future of International Law: Global Government (Cambridge, Cambridge University Press, 2013).

${ }^{75}$ Cf BS Chimni, 'International Institutions Today: An Imperial Global State in the Making', European Journal of International Law (2004).

${ }^{76}$ But see M Koskenniemi, 'The Subjective Dangers of Projects of World Community', in A Cassese (ed), Realizing Utopia: The Future of International Law (Oxford, Oxford University Press, 2012), 3-13; as well as the other contributions in Part 1 of this volume under the heading 'Can the World become a Global Community'?
} 
The trigger may very well have been formed by the sanctions regimes of the United Nations Security Council, ${ }^{77}$ but the study of the effects on individuals was much broader and has led to new areas such as Global Administrative Law. ${ }^{78}$ In general, where traditionally the 'contractual' relations between states were at the forefront, the 'publicness' of international law is gaining more attention. $^{79}$ Obviously, this development raised new questions - not only related to the constitutionalisation of the international legal order, but also to the legitimacy of the decisions or the accountability of the actors. ${ }^{80}$ While 'constitutionalism' is a more general theme in current international legal discourse $e^{81}$ the increasing autonomy of international organizations (or at least the perception that this is the case) has triggered a new stream of literature, which basically aims to apply (variations of) constitutional and similar state-oriented notions related to the rule of law, such as 'administrative governance, ${ }^{82}$ to international organizations. ${ }^{83}$

In general, it has been argued that international law benefits from its more evolved, more constitutionalised parts. International organizations could be seen as 'laboratories of international law. ${ }^{84}$ The EU in particular has 'experimented' with supranational rule making, compulsory jurisdiction, strong enforcement mechanisms, and a strong subjectivity of the individual. ${ }^{85}$ Indeed, over the years, the EU developed quite sophisticated ways to allow individuals effected by EU law to address these issues, either before their domestic courts or before the European court. Targeted sanctions regimes, such as the ones at stake in the Kadi cases, ${ }^{86}$ in particular, made us aware that similar notions were needed at the international level and have been picked up and analysed by studies on the 'direct effect' of decisions of international organizations on individuals. ${ }^{87}$

\footnotetext{
77 cf C Eckes, EU Counter-Terrorist Policies and Fundamental Rights: The Case of Individual Sanctions (Oxford, Oxford University Press, 2009).

78 Among the many publication in this area, one to mention is perhaps N Krisch, 'The Pluralism of Global Administrative Law', European Journal of International Law (2006) 262-274.

${ }^{79}$ See S Kadelbach, above; as well as RA Wessel, 'Revealing the Publicness of International Law', in C Ryngaert, EJ Molenaar, and S Nouwen (eds), What's Wrong With International Law? - Liber Amicorum A.H.A. Soons (Leiden/Boston, Martinus Nijhoff Publishers, 2015) 449-466. Recently also A von Bogdandy, M Goldmann and I Venzke, 'From Public International to International Public Law: Translating World Public Opinion into International Public Authority', European Journal of International Law (2017), 115-145.

80 See also J Klabbers, 'Law-Making and Constitutionalism', in J Klabbers, A Peters, and G Ulfstein (eds), The Constitutionalization of International Law (Oxford, Oxford University Press, 2009), at 12, arguing that non-state actors have "started to compete with states for the scarce resource of politico-legal authority (i.e. the power to set authoritative standards)." In general, the book discusses international constitutionalism as a framework within which further normative debate on a legitimate and pluralist constitutional order can occur (Klabbers, at 10). But see also J Pauwelyn, RA Wessel and J Wouters, 'When Structures Become Shackles', above, where we have argued that the effects on legitimacy should not be overestimated as the traditional 'thin state consent' is replace by a 'thick stakeholder consensus'.

${ }^{81}$ See for instance J Klabbers, A Peters and G Ulfstein (eds), The Constitutionalization of International Law (Oxford, Oxford University Press, 2009); and A Peters, 'Are we Moving toward Constitutionalization of the World Community', in A Cassese (ed), Realizing Utopia: The Future of International Law (Oxford, Oxford University Press, 2012) 118-135.

82 See PL Lindseth, 'Supranational Organizations', in Cogan, Hurd and Johnston, above, 152-170. Lidseth argues that an 'administrative' approach, rather than the 'constitutionalisation' approach is more helpful to classify international organizations along an intergovernmental-supranational axis.

${ }^{83}$ See the various chapters on Legitimacy (Dominik Zaum), Participation (Patrizia Nanz and Klaus Dingwerth), Accountability (Mathias Koenig-Archibugi) and Transparency (Jonas Tallberg) in Cogan, Hurd and Johnston, above. ${ }^{84} \mathrm{C}$ Walter, 'International Law in a Process of Constitutionalization,' in Nijman and Nollkaemper, above, 191 at 214.

85 Ziegler, 'The Relationship between EU Law and International Law', above, at 2.

86 See for instance Eckes, above; as well as RA Wessel, 'The Kadi-case: Towards a More Substantive Hierarchy in International Law?', International Organizations Law Review (2008) 323-327.

${ }^{87}$ See, recently, P Schmitt, Access to Justice and International Organizations: The Case of Individual Victims of Human Rights Violations (Cheltenham (UK)/Northampton (USA), Edward Elgar Publishing, 2017).
} 


\subsection{Democracy and legitimacy}

Irrespective of these developments - or, indeed, as a result of them - another trend is visible as well: back to the state. The reason is that global and EU initiatives are less easily accepted by citizens - as is exemplified by the debates on large regional trade and investment initiatives such as TTIP, CETA, but also by Association Agreements concluded by the $\mathrm{EU}^{88}$ or, indeed, by 'Brexit' ('taking back control'). The developments indeed seem to be connected. Fahey has argued that "the merger of sovereignty, territoriality and jurisdiction in a global world is an emerging matter for EU law". 89 At the same time effects of 'post-nationalism' or 'post-sovereignty' increasingly lead to popular protest: "An aggrandizement of EU influence, competence, scope and even territory may increasingly score lowly in terms of social legitimacy, both inside and outside the EU." $" 90$

Both international and EU law are currently struggling with keeping the populations onboard in the ongoing process of globalisation and Europeanisation. The idea of representing the people in parliaments at international organizations is of course best implemented at the EU, but also visible in a number of other international organizations. ${ }^{91}$ More in general, the struggle for legitimacy is something that the EU and other international fora share and where best (and worst) practices may be shared.

\subsection{The autonomy of international organizations and international responsibility}

The already mentioned development in which international organizations have more and more become international actors in their own right, ${ }^{92}$ also leads to questions that have been part of EU legal doctrine. The division of competences between the EU and its Member States is a fact that has to be recognised by third parties, both when they wish to conclude international agreements and when issues of international responsibility emerge. In the words of Ličkóva: "The complexity of the EU legislation that incidentally generates international consequences makes the international situation of the Member States more difficult every day. For this reason, the EU and its members have introduced legal tools that, if consented to by third parties, endow the international obligations of the EU states with flexibility. It seems that third parties have indeed paid attention to the peculiar nature of the EU legal order and to the specific legal position in which the EU states often operate. A generalized understanding has emerged that whenever an EU Member State comes to the international-negotiation table, the European-law implications will be part of the agenda. Accordingly, third parties adjust to this state of affairs, and the question today is whether this EUfriendly treatment has reached the status of an international custom. " ${ }^{93}$ Indeed, the introduction in the international legal order of an entity of which the members are also international legal person in their own right and where competences and responsibilities are divided among them, ${ }^{94}$ already had an impact on the traditional view in international law that 'domestic' arguments are usually not so relevant to assess international obligations.

\footnotetext{
${ }^{88}$ G Van der Loo, 'The Dutch Referendum on the EU-Ukraine Association Agreement: Legal Implications and Solutions', Netherlands Yearbook of International Law 2016, 2017 (forthcoming).

${ }^{89}$ Fahey, above, at 12.

${ }^{90}$ Ibid. at 15.

${ }^{91}$ See http://www.internationaldemocracywatch.org/index.php/international-parliamentary-assemblies

${ }^{2} \mathrm{ND}$ White and R Collins (eds), International Organizations and the Idea of Autonomy: Institutional Independence in the International Legal Order (Routledge, 2011).

${ }^{93}$ Ličková, above, at 464.

${ }^{94}$ cf RA Wessel, 'The European Union as a Party to International Agreements: Shared Competences, Mixed Responsibilities', in A Dashwood and M Maresceau (eds), Law and Practice of EU External Relations - Salient Features of a Changing Landscape (Cambridge, Cambridge University Press, 2008) 145-180.
} 
As the 2011 Articles on the Responsibility of International Organizations (ARIO) reveal, ${ }^{95}$ a division of competences between IOs and their member states has become a more general issue. The complexity of the division of competences between the EU and its Member States remains unique, but at the same time other international organizations (including the UN) have shown difficulties to establish a clear line of demarcation when questions of international responsibility occur. While the EU has been struggling for quite a while to clarify its internal division of competences to third states (e.g. through the use of so-called 'Declarations of competence ${ }^{96}$ ), the recent 'Srebrenica' cases before courts in The Netherlands exemplify the increasing problem of drawing clear lines of demarcation between, in this case, the United Nations' and Member State responsibilities. ${ }^{97}$

\subsection{Statehood, territoriality and legal personality}

As mentioned above, the EU is assuming more and more state-like functions. At the same time, as a non-state actor there is only so much the EU can do to participate in a state-based system. Yet, even territorial questions do seem to come up even in EU law - including the Court's case law ${ }^{98}$ and a connection with doctrinal issues on that point seems helpful as notions of territory and jurisdiction are central in international law. Buxbaum argued that sovereignty, territory and jurisdiction are the greatest challenge of law across borders in the global legal age. ${ }^{99}$ Indeed, state sovereignty implies that states are the sole rule makers and rule enforcers within a jurisdiction that is closely linked to their territory. The question of whether in the case of international organizations one may speak of a 'territory' is somewhat unsettled in international law. ${ }^{100}$ During the process of drafting the Convention on the Law of Treaties, the International Law Commission had difficulties in accepting the existence of a 'territory of the organization'. ${ }^{101}$ Despite its 'state-like' characteristics,

\footnotetext{
${ }^{95}$ See on the specific position of the EU: PJ Kuijper and E Paasivirta, 'Further Exploring International Responsibility: the European Community and the ILC's Project on Responsibility of International Organisations' , International Organizations Law Review (2004), 111; as well as in general on the ARIO, the special issue of the same journal, 2009, issue no. 1.

${ }^{96}$ See on this issue and on EU international responsibilities in general Delgado Casteleiro, above.

${ }^{97}$ See for instance P Palchetti, 'Attributing the Conduct of Dutchbat in Srebrenica: the 2014 Judgment of the District Court in the Mothers of Srebrenica Case’, 62 Netherlands International Law Review 2 (2015) 279-294.

${ }^{9}$ The Court of Justice has been faced with question of territorial scope on a number of occasions. To mention some examples: Anastasiou (Case C-432/92) was a case concerning Cyprus, before it became an EU Member State. The CJEU refused to recognise export certificates from authorities other than those belonging to the Republic of Cyprus (that is to say, those which bear the name 'Turkish Republic of Northern Cyprus') under the EC-Cyprus agreement. In Brita (Case C-386/08) the Court was faced a similar but more complex question of whether goods originating from the West Bank could be included within the EU's free trade agreement signed with the State of Israel and benefit from the preferential treatment allowed for Israeli products in the EU. Other issues came up in the Front Polisario case (see below).

${ }^{99}$ See H Buxbaum, 'Territory, Territoriality and the Resolution of Jurisdictional Conflict', American Journal of Comparative Law (2009) 631. See also H Buxbaum, 'Transnational Legal Ordering and Regulatory Conflict: lessons from the Regulation of Cross-Border Derivatives', 1 UC Irvine Journal of International Law, Transnationals Law and Comparative Law (2016) 91.

100 Article 29 (on the 'Territorial scope of treaties') of the 1986 Vienna Convention basically copied Article 29 of the 1969 Convention and provides: "Unless a different intention appears from the treaty or is otherwise established, a treaty between one or more States and one or more international organizations is binding upon each State party in respect of its entire territory." It is interesting to note that, while international agreements concluded by international organizations are included, the obligations are imposed on "each State party" only.

101 The 1982 ILC Commentary explains this choice in the following terms: "Is it possible to imagine a parallel provision concerning the obligations of international organizations? Despite the somewhat loose references which are occasionally made to the 'territory' of an international organization, we cannot speak in this case of 'territory' in the strict sense of the word. However, since this is so and since account must nevertheless be taken of the variety of situations which the multiple functions of international organizations may involve, it seemed preferable to avoid a
} 
the case of the European Union is not too different. At the same time, its competences to make and enforce rules within a given 'territorial space' are undisputed. While territorial issues have always been prominent in debates on the application of EU law in its overseas countries and regions, ${ }^{102}$ these days we are witnessing an extension of that 'territorial space'. Obviously also as a consequence of the enlarged membership of the EU, but more importantly because of the 'global reach' of EU law, ${ }^{103}$ and its extra-territorial effects. ${ }^{104}$ Ever more studies have stressed the importance of this phenomenon as well as its impact on international law. As phrased by Joanne Scott: the EU 'makes frequent recourse to a mechanism that may be labelled 'territorial extension.' The practice of territorial extension enables the EU to govern activities that are not centered upon the territory of the EU and to shape the focus and content of third country and international law." 105 This may also lead to jurisdictional questions, e.g. with respect to international law notions of the concept. ${ }^{106}$

While it is not completely alien to the Court to refer to the 'territory of the EU', ${ }^{107}$ the many references to 'territory' in the EU Treaties are mainly related to the Member States' territories. ${ }^{108}$ Nevertheless, it has been claimed that "it is clearly possible to speak of the emergence of the concept of Union territory, given the autonomous demarcation of the territorial application of EU law defined in the Treaties". ${ }^{109}$ Indeed, one may find some hints at the possible existence of an "EU territory', in particular in relation to 'economic, social and territorial cohesion', which intends to

formula which was too rigid or too narrow. If the draft articles said that, in the case of an international organization which is a party to a treaty, the scope of application of the treaty extended to the entire territory of the States members of that organization, the draft would diverge from article 29 of the Vienna Convention by raising the question of the scope of application of a treaty, which is not expressly covered by that Convention."

102 See, inter alia, J Ziller, 'Outermost Regions, Overseas Countries and Territories and Others after the Entry into Force of the Lisbon Treaty', in D Kochenov (ed), EU Law of the Overseas (The Hague, Kluwer Law International, 2011) 69; J Ziller, 'Flexibility in the Geographical Scope of EU Law: Diversity and Differentiation in the Application of Substantive Law on Member States' Territories', in G de Búrca and J Scott, Constitutional Change in the EU, (Oxford, Bloomsbury, 2000), at 119; D Kochenov, 'The Application of EU Law in the EU's Overseas Regions, Countries, and Territories After the Entry into Force of The Treaty of Lisbon', 20 Michigan State International Law Review (2012) 669.

${ }^{103}$ E Fahey, The Global Reach of EU Law (Abingdon and New York, Routledge, 2016).

104 cf J Scott, 'Extraterritoriality and Territorial Extension in EU Law', 62 American Journal of International Law (2014) 87-126; J Scott, 'The New EU Extra-territoriality', 51 Common Market Law Review (2014) 1343.

$105 \mathrm{~J} \mathrm{Scott}$, 'Extraterritoriality and Territorial Extension in EU Law', above, at 89. In this paper, Scott is actually challenging the notion of 'extraterritoriality' as it commonly used in the literature, and draws attention to 'territorial extension': "a measure will be regarded as extraterritorial when it imposes obligations on persons who do not enjoy a relevant territorial connection with the regulating state. By contrast, a measure will be regarded as giving rise to territorial extension when its application depends upon the existence of a relevant territorial connection, but where the relevant regulatory determination will be shaped as a matter of law, by conduct or circumstances abroad." (at 90). For the present contribution it suffices to note that both notions are relevant to underline the need to understand both international and EU law systematics.

106 A case in point was formed by the Ebony Martime case, where the question arose of the compatibility of an EU Regulation on the enforcement of sanctions and the freedom of the high seas under international law. See Case 177/95, Ebony Maritime SA and Loten Navigation Co. Ltd v Prefetto della Provincia di Brindisi and others, ECLI:EU:C:1997:89.

107 See for instance the frequent use of the term 'Community territory' in the Ebony Maritime case, above. Other cases in point may be Case C-34/09, Gerardo Ruiz Zambrano v Office national de l'emploi, ECLI:EU:C:2011:124; and case C434/09, Shirley McCarthy v Secretary of State for the Home Department, ECLI:EU:C:2011:277. cf D Kochenov, 'A Real European Citizenship; A New Jurisdiction Text; A Novel Chapter in the Development of the Union in Europe' 18 CJEL 56 (2011).

108 See extensively as well as much more in detail on these provisions: D Kochenov, 'European Union Territory from a Legal Perspective: A Commentary on Articles 52 TEU, 355, 349, and 198-204 TFEU', in M Kellerbauer, M Klamert and J Tomkin (eds), The EU Treaties and the Charter of Fundamental Rights - A Commentary (Oxford, Oxford University Press, 2018 (forthcoming); University of Groningen Faculty of Law Research Paper 2017-05; available at SSRN: https://ssrn.com/abstract=2956011.

109 Ibid., at 3. 
view the territories of the Member States as a whole. ${ }^{110}$ With regard to third country nationals (TCNs), the EU's common immigration policy (Art. 79 TFEU) provides other arguments to start viewing the territories of the EU Member States as one 'EU territory'. More in general, the internal market rules seem to point to the, at least 'virtual' existence of a common EU territory. More clear notions of a possible 'EU territory' can be found when the 'territorial application' of the Treaties in concerned. First of all, the Treaties apply to the EU Member States (which are all mentioned by name). ${ }^{111}$ This is further specified in relation to the so-called countries and territories overseas, which leads to an extension of the territorial scope of the EU. ${ }^{112}$ At the same time, the existence of overseas territories may have territorial implication under, for instance, the law of the sea, in particular where these territories may result in an additional economic exclusive zone (EEZ) to be used for fishing and possible mining activities. Thus, while EU law is not (fully) applicable to Greenland, it's location does lead to an interest of the EU in debates on the future of the arctic area.

Finally, the present author's - admittedly - mild obsession with the notion of legal personality, ${ }^{113}$ warrants a few lines on that issue. First of all, international law perspectives have been used in EU law scholarship to answer the question of the EU's own legal personality or the legal status of its agencies. ${ }^{114}$ These notions have been important to establish the EU's separate legal status as a global actor alongside its Member States. Furthermore, more recently the EU also seems to give its own interpretation to the notion. A recent case in point is the Front Polisario case, ${ }^{115}$ which dealt with the territorial application of a trade agreement between the EU and the Kingdom of Morocco. ${ }^{116}$ Indeed, the case has "fascinating international law aspects". ${ }^{117}$ Apart from the territorial questions, the case also dealt with the recognition of the claimant, the Polisario Front a national liberation movement (NLM) that claims sovereignty for Western Sahara - as a natural or legal person under Article 264(4) TFEU. The General Court combined international as well as EU law arguments to decide on the NLM's legal personality. ${ }^{118}$ In the further definition and

\footnotetext{
110 Thus, Article 3(3) TEU refers to the Union's objective to "promote economic, social and territorial cohesion, and solidarity among Member States." At the same time "It shall respect its rich cultural and linguistic diversity, and shall ensure that Europe's cultural heritage is safeguarded and enhanced.". References like these are meant to create some unity while preserving the diversity, and the objective of 'territorial cohesion' has merely been the driver behind the allocation of the so-called cohesion funds aimed at "reducing disparities between the levels of development of the various regions and the backwardness of the least favoured regions."(Art. 174 TFEU).

111 Art. 52 TEU.

112 Art. 355 TFEU.

113 See for instance RA Wessel, 'Reparation for Injuries Suffered in the Service of the United Nations', in C Ryngaert, IF Dekker, RA Wessel and J Wouters (eds), Judicial Decisions on the Law of International Organizations (Oxford, Oxford University Press, 2016) 11-18; or in the same volume RA Wessel, 'Legal Status (Personality)', 6-10; NM Blokker and RA Wessel, 'Revisiting Questions of Organizationhood, Legal Personality and Membership in the OSCE: The Interplay Between Law, Politics and Practice', in M Platise Steinbrück, C Moser, A Peters (eds), Revisiting the Legal Status of the OSCE, 2018 (forthcoming); or earlier RA Wessel, 'Revisiting the International Legal Status of the EU', European Foreign Affairs Review (2000), 507-537; and RA Wessel, 'The International Legal Status of the European Union', European Foreign Affairs Review (1997) 109-129.

114 See for references the final two publications in the previous footnote.

115 Case T-512/12, Frente Polisario v. Council, 2015

1162010 EU-Morocco Agreement on agricultural, processed and fisheries products,

117 See Geraldo Vidigal, 'Trade Agreements, EU Law, and Occupied Territories - A Report on Polisario v Council', EJIL Talk!, 1 July 2015; https://www.ejiltalk.org/trade-agreements-eu-law-and-occupied-territories-a-report-onpolisario-v-council/. See also FG Nicola 'Of Pirates, Occupied Territories and Oil companies: The Quiet Diplomacy of the European Court of Justice' paper presented at the Workshop Workshop EU Trade Law and Policy: Current Developments and Challenges, Università LUISS Guido Carli, Rome, Italy, 10 April 2017.

118 Case C-72/15, Opinion of Advocate General Wathelet, 31 May 312016.
} 
development of international legal personality, both EU and international law scholarship will find new material in cases like these.

\subsection{Citizenship and nationality}

There is a clear link between territory, nationality and citizenship. While nationality is usually related to a particular state, citizenship can also be granted to others living on the territory of that state. European citizenship is a key element of the process of European integration. Art. 30(2) TFEU inter alia provides: "Citizens of the Union shall enjoy the rights and be subject to the duties provided for in the Treaties. They shall have [...] the right to move and reside freely within the territory of the Member States". Indeed, the territory of all Member States; the rights of European citizens have largely been harmonised and European citizenship is frequently used by the Court of Justice of the EU to rule on extensive rights for individuals. Citizenship has thus become an essential element in the right to seek or accept jobs, to start a business or to provide cross-border services. At the same time, European citizenship entails "the right to enjoy, in the territory of a third country in which the Member State of which they are nationals is not represented, the protection of the diplomatic and consular authorities of any Member State on the same conditions as the nationals of that State $[\ldots]$ ". ${ }^{119}$ Hence, outside the EU a European citizen may rely on the help of another EU Member State. Thus, the traditional national diplomatic and consular assistance is extended to an EU-wide system of protection of European citizens abroad. Links with international diplomatic and consular law become ever more visible. ${ }^{120}$

While, currently, the idea of 'supranational citizenship" ${ }^{\text {"121 }}$ can most easily be seen as a dimension of the European integration process, it has been argued that the existence of the phenomenon could allow for a more general separation between states and (single) citizenship: "This belonging to a polity, expressed in purely legal terms, is the real novelty of the European model, replicable in other geographical areas or global organizations - which could generate - one day - their one partial citizenships - and it opens the door to multiple and cumulative citizenships, not conflicting among each other, to communities partially overlapping." 122

At the same time, it is clear that EU citizenship does not endow the EU with competences states would generally have under international law to protect their nationals. In international diplomatic and consular law, the notion of nationality remains crucial. New developments in EU diplomacy reveal at least an ambition of the EU to act on behalf of its Member States in situations of diplomatic protection and consular assistance. This clearly highlights the parallels between being a national of a state and a European citizen.

\footnotetext{
119 Art. 23 TFEU. Emphasis added.

${ }^{120} \mathrm{~S}$ Duquet, The Contribution of the European Union to Diplomatic and Consular Law, PhD thesis, University of Leuven, 2018; P Kerres and RA Wessel, 'Apples and Oranges? Comparing the European Union Delegations to National Embassies', CLEER Papers 2 (2015); RA Wessel, 'Can the European Union Replace its Member States in International Affairs? An International Law Perspective', in I Govaere, E Lannon, P Van Elsuwege, S Adam (eds), The European Union in the World: Essays in Honour of Marc Maresceau (Leiden/Boston, Martinus Nijhoff Publishers, 2013) 129-147; RA Wessel and B Van Vooren, 'The EEAS' Diplomatic Dreams and the Reality of International and European Law', Journal of European Public Policy 9 (2013) 1350-1367.

${ }^{121}$ See F Strumia, Supranational Citizenship and the Challenge of Diversity: Immigrants, Citizens and Member States in the EU (Leiden/Boston, Brill | Nijhoff, 2013).

122 S Cafaro, 'Peculiarities of a Supranational Citizenship', 21 November 2016, available on https://www.linkedin.com/pulse/peculiarities-supranational-citizenship-susanna-cafaro
} 
A classic difference between EU and international law is perceived to be found in the availability of legal instruments. Under EU law, 'legally binding' decisions can be taken, that - in most cases can even be enforced before a Court of law. International law would have to rely on politics and persuasion rather than on legal instruments. Obviously, this is a caricature of both EU and international law. Large parts of the European integration process are based on 'softer' instruments, including all kinds of 'green or white papers' of the European Commission, resolutions by the European Parliament, Declarations by the European Council or instruments such as the 'open method of coordination'. ${ }^{123}$ The main source of international law, on the other hand is formed by the thousands of (legally binding) treaties concluded between states and international organizations; and quite a few international organizations have the competence to enact binding decisions. ${ }^{124}$ While enforcement possibilities indeed differ, one can hardly maintain that the daily practice in the $\mathrm{EU}$ is based on legally binding instruments and the daily practice in international law is not. Both international and EU law have a variety of (legal) instruments at their disposal and - given the above-mentioned similar questions they are faced with - there are no a priori reasons to study the use and effects of these instruments in complete isolation.

A different, yet related, question concerns the hierarchy between international, EU and domestic legal norms as well as their inter-relationship. While the principle of 'primacy' of EU law over the law of its member States is rightfully seen as a cornerstone of the EU's legal system, in practice the difference with international law norms may be less clear. It is easy to point to some differences (e.g. under EU law domestic courts seem to have to accept the primacy of EU law even within their own legal order), but it is perhaps more interesting to assess some of the parallels (e.g. international law is also binding on states and, domestically, they may also be forced find solutions to square possibly conflicting national and international norms). ${ }^{125}$ Moreover, in finding solutions for potentially conflicting norms in a situation of 'multilevel regulation', ${ }^{126}$ both EU and international law use similar techniques, such as 'treaty conform interpretation' or 'consistent interpretation' to allow for norms at different levels to coincide without conflict. ${ }^{127}$ A comparison of the practical application of these principles in EU, international and domestic law may very well lead to new insights in the way in which legal norms have an effect in different legal orders.

\section{Conclusion: towards a more integrated study of international and EU law?}

First reactions to presentations of drafts of this contribution where telling and ranged from disapproval to almost sheer panic. Was I really suggesting to get rid of the distinction between

\footnotetext{
123 cf A von Bogdandy, F Arndt, and J Bast, 'Legal Instruments in European Union Law and Their Reform: A Systematic Approach on an Empirical Basis', Yearbook of European Law (2004) 91-136; M Ruffert, 'The Many faces of Rule-Making in the EU', in E Fahey (ed), The Actors of Postnational Rule-Making: Contemporary Challenges of European and International Law (Abington/New York, Routledge, 2016) 47-66. See on soft law in the EU for instance: F Terpan, 'Soft Law in the European Union: The Changing Nature of EU Law', European Law Journal (2014) 40.

124 cf IF Dekker and RA Wessel, 'Governance by International Organisations: Rethinking the Source and Normative Force of International Decisions', in IF Dekker and W Werner (eds), Governance and International Legal Theory (Leiden/ Boston, Martinus Nijhoff Publishers, 2004).

125 cf Nijman and Nollkeamper, above.

${ }^{126}$ Føllesdal, Wessel and Wouters, above

127 See for instance DT Björgvinsson, The Intersection of International Law and Domestic Law: A Theoretical and Practical Analysis (Edward Elgar, 2015), Chapter 6.
} 
international and EU law in our curriculae? Did I not see that the two fields of study were so different that combining them would not do justice to their respective peculiarities? Did I deliberately ignore the fact that for both sub-disciplines it is already impossible to find generalists and that combining them could only lead to superficial analysis? Of course I am aware of all this. In fact, the gap between international and EU law I witnessed while teaching at various universities in Europe formed exactly the reason to look for bridges. Once students have chosen their specialisation, they tend to lock themselves up in their new disciplinary cage. And, frankly, we help them doing so by not drawing attention to the interactions between different legal systems. It is not unusual for graduate students to respond: 'I'm sorry I'm doing EU law, I know nothing about public international law" (and vice versa), while their undergraduate courses in these fields where only one or two years ago.

In reaction to these somewhat defensive statements, a useful reassurance may be that - as phrased by Bruno de Witte - "qualifying EU law as international law does not imply that the Treaties should be understood and interpreted from an intergovernmental perspective and that limitations of sovereignty should be narrowly construed". ${ }^{128}$ The many specific, and valuable, characteristics of the EU, and of the European integration process more generally, are undeniable and warrant a continued in-depth study. The mere aim of the present contribution was to draw attention to a number of areas in which the study of both international and EU law should remain to be aware of doctrinal developments. True, it is hardly possible in any of these two areas to remain a generalist, given the advanced and often quite complex and technical details that by now characterise most sub-disciplines in international and EU law. A plea to try and even go beyond that may be wishful thinking and perhaps, indeed, even result in far too superficial analyses. After all, any comparison becomes easier at a higher level of abstraction.

The aim of this contribution is therefore more modest. Noticing a deepening of the divide between international and EU law scholarship and the reflection of this is our educational programs, the question was whether we could indicate issues in one discipline of which it makes sense to be included in analyses of the other. While there are certainly exceptions, it is quite strange that in EU law programs hardly any attention is paid to treaty law, trade law, statehood, the law of international responsibility, international organizations law or (these days) diplomatic law. Similarly, why do courses on the law of international organizations mostly continue to exclude the EU and the institutional developments in that organization? And, why do we hardly see a comparison to EU enforcement mechanisms, negotiations and decision-making, institutional solutions, democratic experiments or variations of legal acts in general course on international law?

This contribution briefly analysed the mutual perspectives of international and EU law and mapped a number of areas in which these disciplines can continue to learn from each other. While admitting the somewhat EU-centric locus of the plea, ${ }^{129}$ both the study of the further institutionalisation of the international legal order and the study of the internal and external relations of the EU may benefit from that exchange of thoughts. As a result of the increasing global interests of the EU, the mutual influence of international and EU law on each other's development seems to be getting more attention in recent academic research. This may form a logical momentum to get reacquainted and renew the dialogue.

\footnotetext{
128 De Witte, 'EU Law: Is it International Law?', above, at 196.

${ }^{129}$ Indeed, the entire discussion is far less relevant for law students in Asia, Africa or the Americas.
} 